\title{
Student Trade Missions: An Experiential Learning Opportunity
}

Josée Audet, Université Laval, Canada

Geneviève Marcotte, Université Laval, Canada

\begin{abstract}
In response to the criticisms addressed to business schools, teaching formulas that foster experiential learning are increasingly being put forward. The Missions Commerciales de l'Université Laval (MCUL-Université Laval Trade Missions) is a training program designed to foster experiential learning. This program extends over an entire academic year in which students are required to find and fulfill an international development mandate on behalf of a business. The objective of this study is to investigate the extent to which participation in such a business consulting project enables students to acquire new skills and modify certain attitudes. Our results show that student participation in an international trade mission has a considerable impact on the acquisition of professional skills and competencies, as well as the development of personality traits and attitudes. Through this experience, students build confidence, develop a sense of initiative and learn to identify business opportunities and adapt quickly. It allows them to sharpen their sales skills and techniques while learning to represent a business. Having completed a trade mission also appears to improve student employability.
\end{abstract}

Keywords: Experiential Learning; Business Consulting Project; Trade Mission; Learning Outcomes

\section{INTRODUCTION}

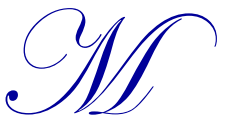

any voices have been raised to question the value of the education provided in business schools (Bach, 2012; Datar, Garvin \& Cullen, 2010; Holtom \& Porter, 2013), and it has become evident that a change in direction is needed. An often-heard criticism is that the teaching is too theoretical and does not adequately prepare students for the labour market. More specifically, there appears to be a significant disconnect between MBA programs' curricula and the skills that potential employers look for in graduates (Pfeffer \& Fong, 2002; Rubin \& Dierdoff, 2009; Rubin \& Dierdoff, 2011). One of the avenues that should perhaps be considered to remedy this shortcoming is to prioritize a pedagogical approach based on experiential learning (Brown, Ben Arbaugh, Hrivnak, \& Kenworthy, 2013), such as can be provided through business consulting projects. The objective of this study is to investigate the extent to which participation in a business consulting project enables students to acquire new skills and modify certain attitudes. The pedagogical context of this study is centred around the Missions Commerciales de l'Université Laval (MCUL- Université Laval Trade Missions), a training program that extends over an entire academic year in which students are required to find and fulfill an international development mandate on behalf of a business.

A review of the literature will first provide context to the concept of experiential learning. Student experience as part of the Trade Missions will then be described in depth to provide a proper understanding of the learning context. Parallels will be drawn with Experiential Learning Theory to assess the degree to which the educational framework of the Trade Missions corresponds to the model put forward by Kolb (1984), and to see how this translates into reality. The methodology used to identify the Trade Missions' impacts and to measure the learning outcomes will be explained. A presentation of the results and data analysis will provide an opportunity for an insightful discussion of the pedagogical model upon which the Trade Missions program is based as well as the broader impacts of this initiative. As this study is of an exploratory nature, its limitations will be underscored, and promising avenues for future research emanating from this study will be put forward. 


\section{LITERATURE REVIEW}

Experiential Learning Theory (ELT) has inspired management education and research for nearly half a century. This theory put forward by D. A. Kolb (1984) is rooted in the work of leading researchers such as John Dewey, Kurt Lewin and Jean Piaget. ELT is a dynamic view of learning based on a learning cycle in which the learner travels through four steps: concrete experience, reflective observation, abstract conceptualization and active experimentation (Kolb \& Kolb, 2009). For students, this cycle begins with an experience; a tangible problem with which they are faced. They then reflect on and critically examine this experience from multiple perspectives. For abstract conceptualization, students use logic and reasoning to understand what they have experienced to ultimately use the knowledge gained to make predictions and test new hypotheses in a new situation (Ramburuth \& Daniel, 2011). Learning is therefore achieved by taking action, on the condition, however, that learners have the opportunity to take a step back and think about what they have just experienced, draw a lesson from this experience or gain a new understanding of the phenomenon and experience it once again.

Of all the steps in the learning cycle, reflection is one of the most critical (Hughes \& Schultz, 2015). It involves "playing back a period of time related to previous valued experiences in search of significant discoveries or insights about one self, one's behaviour, one's values or knowledge gained." (Desjarlais \& Smith, 2011, page 3). To achieve this, previously held beliefs and assumptions must be made explicit. Reflection generally occurs on an individual basis, but it can also be done as a group or within a team which, in the opinion of some researchers, makes the exercise even more productive as greater competence is developed via the social interaction and dialogue that occur when students discuss among themselves and share their points of view (Knapp, 2010; Ohlsson, 2013). The results of Miller and Maellaro (2016) underscore the fact that by compelling students to aggregate their individual reflections into a consensus reflection for the team, the students have the opportunity to reflect once again from the new angle their experience has provided.

In an academic context, it is important that the experience be as close as possible to a real situation in which students will eventually find themselves. Case studies, simulations and role playing activities are in fact approximations of reality. Corporate internships, consultancy or intervention projects provide the ideal terrain for experiential learning, to the extent, obviously, that they are designed to enable students to travel through the four steps of the learning cycle. Accompanying students in this type of learning also requires special skills on the part of the educator that differ from those required in more traditional classroom teaching. In the opinion of Kolb, Kolb, Passarelli and Sharma, (2014), "the techniques of facilitation such as debriefing learning experiences, drawing out and building on the prior knowledge of learners, and facilitating a climate of trust and open communication are, but one facet of a holistic process of learning from experience that also includes expert knowledge input, evaluation, and coaching on learning strategies." (page 208). These skills are put to use at different moments in the learning cycle, based on the role the educator is required to fulfill. These authors identified four roles that correspond to the four steps in the learning cycle: facilitator, subject expert, standard-setter/evaluator and coach. To maximize the learning outcomes, it is important that educators be capable of fulfilling all of these roles. In actual fact, however, it would appear that we all have a certain preference for some roles over others, whether as a result of a preferred teaching style or philosophy.

Several authors have focused on the potential impact of experiential learning on learning outcomes. Given that educational activities that include experiential learning can be incorporated into the curricula of a wide range of disciplines, learning outcomes are likely to be quite varied. In terms of management education specifically, a sample of the most frequently observed and most representative outcomes in the recent literature is listed in Table 1 below. A very useful learning outcome classification system has been put forward by Kosnik, Tingle and Blanton III (2013), who are of the opinion that "an effective business curriculum should deliver three distinct sources of educational value: 1) academic value, 2) professional value and 3) moral value" (page 614). The listed outcomes are therefore presented according to the type of value they deliver to the curriculum. It should be noted that most of the experiential learning outcomes appear in the last two categories, as those associated with academic value are usually generated from basic business courses, most of which are taught using a more traditional approach. 
Table 1. Learning outcomes related to business education

\begin{tabular}{|c|c|c|}
\hline \multirow{3}{*}{ Academic Value (business knowledge) } & Critical thinking $^{12}$ & \\
\hline & Global business awareness/mindset ${ }^{34}$ & \\
\hline & Enterprising mindset ${ }^{5}$ & \\
\hline \multirow{5}{*}{ Professional Value (business skills) } & Teamwork 1236 & $\begin{array}{l}\text { Communication/negotiation skills }{ }^{125} \\
\end{array}$ \\
\hline & Confidence/self-efficacy ${ }^{5}$ & Leadership/ability to direct others ${ }^{1}$ \\
\hline & Self improvement/development ${ }^{34}$ & Managing information overload ${ }^{2}$ \\
\hline & Interpersonal skills/social skills 1256 & Coping with ambiguity ${ }^{2}$ \\
\hline & Selling skills and knowledge ${ }^{7}$ & Time management/planning 125 \\
\hline \multirow{3}{*}{ Moral Value (character) } & Ethical literacy $^{4}$ & \\
\hline & Cultural intelligence ${ }^{4}$ & \\
\hline & $\begin{array}{l}\text { Community building/good citizenship }{ }^{12} \\
\end{array}$ & \\
\hline $\begin{array}{l}{ }^{1} \text { Austin, M. J., \& Rust, D. Z. (2015) } \\
{ }^{2} \text { Kosnik, R. D.,Tingle, J. K., \& Blanton III, E. } \\
{ }^{3} \text { Chmielewski-Raimondo, D., McKeown, W., } \\
{ }^{4} \text { Le, Q. V., \& Raven, P. V. (2015) } \\
{ }^{5} \text { Splan, R. K., Brooks, R. M., \& Porr, C. S. (2 } \\
6 \text { Bell, R., \& Bell, H. (2016) } \\
{ }^{7} \text { Deeter-Schmelz, D. (2015) } \\
{ }^{6} \text { Bell, R., \& Bell, H. (2016) } \\
7{ }^{7} \text { Deeter-Schmelz, D. (2015) }\end{array}$ & $\begin{array}{l}\text { (2013) } \\
\text { Brooks, A. (2016). }\end{array}$ & \\
\hline
\end{tabular}

Academic projects that place students in "real life" simulation situations by confronting them to real problems provide a unique experiential learning opportunity. Such projects should help students "harness their soft and hard skills and bring about cognitive, affective and behavioral changes in students" (George, 2015, p. 3). The following section describes the Trade Missions pathway, which provides students with precisely such an opportunity by having them play the role of a professional actually on the job.

\section{UNIVERSITÉ LAVAL TRADE MISSIONS}

\section{General Description}

For several years now, Université Laval has offered its students the opportunity to participate in trade missions as international development officers. This training program is carried out under the aegis of the Missions Commerciales de l'Université Laval (MCUL - Université Laval Trade Missions), a non-profit organization managed in collaboration with students. Students are responsible for selling the Trade Missions' services to Québec-based businesses, and then preparing and fulfilling the mandates they are awarded in the targeted country. The nature of these mandates is generally to help the businesses penetrate new international markets (market studies, export assistance) or to internationalize their value chain (import assistance, sub-contracting). To benefit from these services, the mandating business must make a lump-sum payment of CAD \$ 7,500, which essentially covers the student's travel expenses and the Trade Missions' operating expenses. Although students are not remunerated for this work, they receive academic credits if they fulfill all of the Trade Missions' academic requirements.

\section{Destinations}

The first edition of the Trade Missions was held in 1997 with 15 business administration students representing Québec businesses in Argentina. Since then, a total of 18 destinations have been visited, several of which on multiple occasions. The destinations change from year to year, although at least one Asian country and one South American country are always represented. One other particularity worthy of mention: from the very beginning, it was decided to exclude the US market as a potential Trade Mission destination. Since the United States is by far Canada's leading trade partner, it was deemed too easy for students to find mandates there and that the sales experience would be diminished as a result. Furthermore, the cultural and language barriers between Canada and the US are rather low, which would have limited the students' opportunity to develop cultural adaptation skills. 


\section{Trade Missions Management and Operations}

The Trade Missions is a non-profit organization headed by a board of directors that includes representatives of Université Laval, business people and Trade Missions alumni. The organization's management includes an academic director and an executive director who work in collaboration with students.

The academic director is a professor with Université Laval's Faculty of Business Administration who ensures that the project's pedagogical component is properly carried out. This is the person who plans the various training sessions throughout the year and who evaluates the assignments written by the coordinators and development officers. The executive director is responsible for the organization's operations. He ensures that objectives are achieved and that the program stays on budget. He orchestrates the recruitment of the coordinators and leads the team to ensure that each member performs the assigned duties. The coordinators and development officers are students who receive academic credits for their involvement.

\section{Coordinators}

The coordinators are former development officers who are selected to act as trade mission leaders. They are the immediate superiors of the development officers. Their first duty is to recruit development officers by generating a pool of candidates via a campus-wide advertising campaign. They supervise and support the officers, in particular by helping them achieve their sales targets. They are also responsible for all of the mission's logistics: budgeting, booking flight and hotel reservations, organizing events at the destination, etc. Lastly, they coordinate the mission's activities once they are on site.

\section{Development Officers}

Development officers are students recruited mainly from business administration, science and engineering, law, communications and international studies programs. On average, more than 200 students submit an application every year for only 40 available positions, which is an indication of the Trade Missions' popularity and notoriety on campus. After two interviews, development officers are selected on the basis of their leadership, motivation, dynamism and eagerness to work abroad.

The first duty of development officers is to contact businesses, Québec-based SMEs in most cases, to try to secure a mandate. To achieve this, every week for nearly five months, they cold-call business leaders to get an appointment to present their services. Searches in various databases are carried out in order to identify major market trends and business opportunities for the targeted businesses. It should be noted that all development officers are responsible for obtaining mandates for the entire group. This means that every officer must continue to search for and visit businesses as long as all of the mandates have not been secured. This is truly a team effort in which strong connections among the students are created. The mandate-seeking period ends in late March, after which the students focus on preparing their mission.

The nature of a mandate is jointly defined by the development officer and the mandating business, and subsequently validated by the coordinator to ensure it is feasible. Once they have been assigned a mandate, development officers begin to familiarize themselves with the business and its products and to further explore opportunities to be seized abroad. Before they embark on their mission, they produce a report that includes an analysis of the targeted market, an interview questionnaire for the scheduled appointments at their destination, as well as an action plan.

In May, the delegations, each of which includes a dozen development officers and two coordinators, leave for a threeweek mission in the targeted countries. In the first days at their destination, the delegation attends a meeting at the Canadian Embassy or Bureau du Québec, depending on the destination. These diplomatic meetings allow the students to validate the work they have done up to that point and, if applicable, schedule additional appointments with foreign companies. On occasion, meetings with local associations or chambers of commerce are also organized for the purpose of expanding their contacts. Over the three-week period, development officers are responsible for meeting with businesses and organizations in order to achieve the objectives set by the clients they represent. Every evening, a team meeting is held in which each person shares a summary of their day, their success stories and obstacles they have 
encountered. Since the teams are multidisciplinary in nature, these team meetings enable each person to share their specific knowledge and to quickly find solutions to continue fulfilling their mandate. In addition to being in constant contact with their client, every Thursday of the mission, the development officers must provide them with a summary of the appointments scheduled over the previous week.

Upon their return from their mission, the development officers draft a report in which they describe what they did during their mission and the results they achieved. They also formulate recommendations regarding future potential internationalization efforts by the company. After the report is evaluated by the academic director, it is presented and submitted to the business, thereby completing the work of the development officer.

\section{Course Associated with the Trade Missions}

To participate in the annual Trade Missions, students must first successfully complete the selection process and then register for the six-credit course related to the Trade Missions experience. This is an elective course that any Université Laval student can take, regardless of program or academic level. The general objectives of the course are to promote understanding of the business world, both in Canada and in the destination country, by securing a mandate to represent a Canadian business, preparing the financial, logistic, commercial, cultural and technical aspects of a business trip and conducting real negotiations with potential clients or partners on behalf of the mandating business.

The course includes a more traditional teaching component in the form of thematic workshops led by various experts in international trade, intercultural management, market development, negotiation, leadership and languages. These weekly workshops begin in October and continue until late April. Concurrently, students undergo practical training in the form of coaching from the coordinators as they carry out start-up activities (cold-calling, scheduling appointments, developing sales pitches, etc.). An office is specifically assigned to them in which they can carry out these activities, with access to telephone lines for calls and computers for database searches. Students are expected to dedicate half a day per week to these activities.

Students are mainly evaluated on the basis of their participation in the activities and their mission reports (predeparture report and final report given to the business). At the end of the process, they must also complete a summary of their experience in which they explain their progression, what they learned from their experience, how they experienced the mission and its preparation, and what left the biggest impression on them, both in terms of the mission and the country they visited. They are also asked to report on their experience with regard to the team dynamics, the difficulties they encountered and how they overcame them. In short, they must put into writing the reflections and actions that resulted from the experiential learning loops they experienced throughout the Trade Missions process.

\section{TRADE MISSIONS AS A GENUINE EXPERIENTIAL LEARNING OPPORTUNITY?}

As several authors have pointed out, experienced-based teaching does not necessarily lead to experiential learning, as the learning activities must be orchestrated in such a way as to lead students to make sense of what they have experienced, and to transform these experiences into new knowledge. This process is facilitated when students complete the four steps of the learning cycle put forward by Kolb (1984). The question here is whether the academic track provided by the Trade Missions corresponds to Kolb's model.

The skills and competencies students develop with the Trade Missions are mostly associated with sales: knowing how to sell a product or service, communicating convincingly, knowing how to negotiate and properly representing the interests of a client, to name but a few. In order to facilitate the acquisition of these skills, the complexity and significance of the tasks students are assigned increase gradually throughout the year. Thus, the first months are dedicated to the search for businesses that are prepared to purchase the Trade Missions' services. Students sell a simple service with a proven track record and a solid reputation. They do not have to negotiate the terms of the agreement (cost, targeted country, length of the stay abroad, etc.), as these have already been determined. Furthermore, they benefit from the sales expertise developed by students for this service over the years, in particular by having access to a list of potential businesses, a compendium of the most successful sales arguments, as well as replies to the mostoften raised objections. In short, they have the advantage of being provided with a fairly complete "sales kit" to guide them in their efforts, all under the watchful eye of a coordinator. In the second part of the Trade Missions, students 
must demonstrate much more independence and initiative. For one, the mandate they are assigned is unique and new. They must handle things on their own to get to know the industry of the client they are representing, understand their client's products or services and identify business opportunities to explore in the country targeted by the Mission. Once on site, they must develop their own sales arguments and negotiate relatively complex contract terms in a culture and language that are foreign to them. In short, students are gradually projected outside of their comfort zone. In order to adequately complete each of the tasks they have been assigned, students must have learned from the preceding task, which was in all likelihood less complex. We therefore have an example of learning cycles in a continuous spiral.

The following example, based on a true story, illustrates the manner in which students move iteratively from one step to the other in the learning model put forward by Kolb (1984).

A student was assigned a mandate to identify potential customers in Mexico for a business in Québec that markets frozen small Northern shrimp. When he first arrived in Monterrey, he targeted seafood distributors. Their response was unanimous: there is no market for Northern shrimp in Mexico; Mexicans prefer local shrimp and are used to eating large shrimp. They showed absolutely no interest in the product he was trying to sell. During the group debriefing session held at the end of each day of the mission, the student shared his rather disappointing experience. From the ensuing discussions emerged the idea of changing targets, and to go directly to the supermarkets or restaurants. Back in his hotel room, the student reflected on his experience that day as he also recalled the concepts of marketing strategy, distribution channels, "push" and "pull" sales strategies and market influencers that were discussed in international trade and marketing seminars he had attended. He prepared his game plan for the next day: he would go straight to the restaurants, targeting renowned chefs who were more likely to be interested by a fine and exotic product. If he could manage to win them over with his product, they would be the ones to pressure the distributors to supply them with Northern shrimp, and the product would become a must-have food item. In the days that followed, the student searched the Internet to identify Monterrey's most chic and trendy restaurants, contacted the chefs who worked there and set off to meet them. In order for the chefs to be able to taste and prepare this delicacy, he took great care to bring samples of Northern shrimp he had kept frozen at his hotel. The product was an instant hit: the chefs wanted access to this product that stood apart from Mexican shrimp at any cost. To cement the "pull" effect, the student asked the chefs to provide him with a letter confirming their interest in buying Northern shrimp. His intention was to use this proof of interest to convince the seafood distributors to do business with the company he was representing. With the letters in hand, he went back to see the distributors, which began a second learning cycle... 
This episode can be schematized as follows using Kolb's model (1984):

Figure 1. Experiential learning cycle within Trade Missions experiences

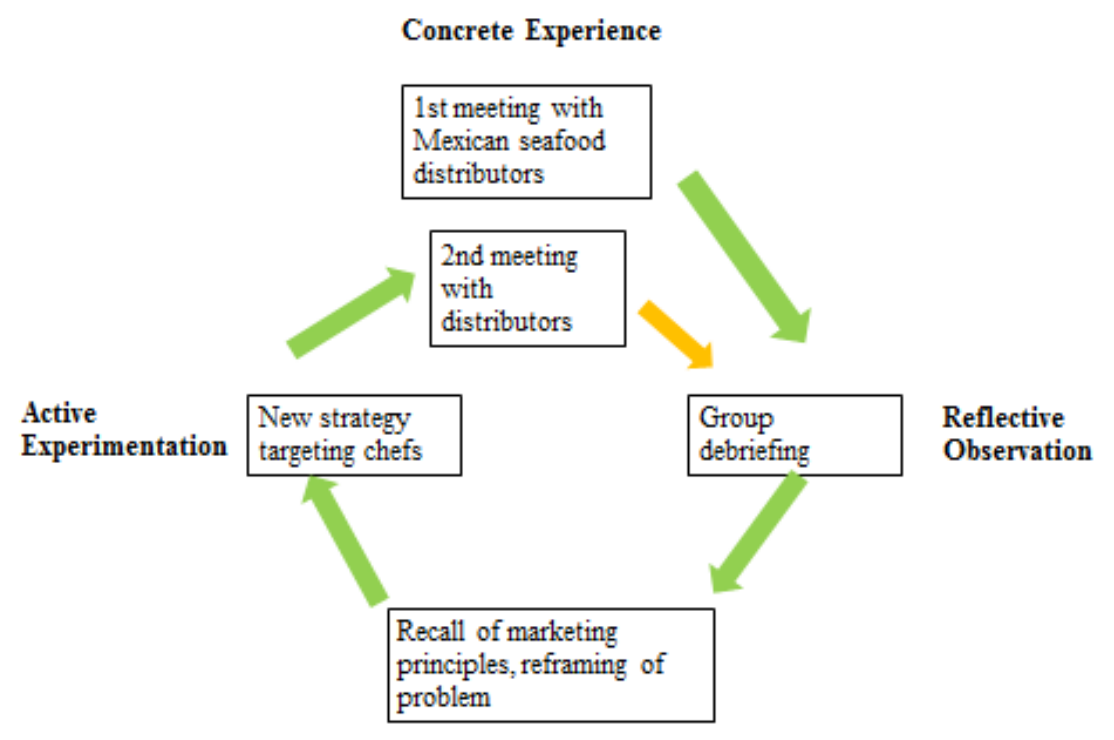

Abstract Conceptualization

It would appear from the facts observed and reported above that the boundaries between the four steps of the learning cycle are rather blurred, in that the student's reflection overlaps the search for links with learned concepts and the development of new experimentation strategies. However, according to Kolb, Kolb, Passarelli and Sharma "while the learning cycle describes an idealized stepwise progression around the cycle ... in reality, learners may proceed to engage the learning modes in different ways based on their learning style and context ..." (2014, page 214).

\section{RESEARCH QUESTION AND METHODOLOGY}

The student experience summaries and informal conversations with students who have completed a mission suggest that student learning outcomes reach far beyond the objectives set in the course outline. More specifically, it appears that the Trade Missions experience has a profound and positive effect on the students' attitudes, personality traits and skills, which leads us to formulate the following question:

What are the principal impacts of the Trade Missions experience on student attitudes, traits and skills?

This exploratory study therefore focuses on the acquisition of soft skills and changes in attitudes by the students, rather than the acquisition of knowledge about international trade. Given that international trade knowledge acquisition goals are already measured using a broad range of graded activities, another pathway was prioritized, which appeared to us to be more promising. In other words, the focus is on outcomes leading to professional value rather than academic value, within the meaning assigned to these concepts by Kosnik et al. (2013).

\section{RESEARCH QUESTION AND METHODOLOGY}

The student experience summaries and informal conversations with students who have completed a mission suggest that student learning outcomes reach far beyond the objectives set in the course outline. More specifically, it appears that the Trade Missions experience has a profound and positive effect on the students' attitudes, personality traits and skills, which leads us to formulate the following question: 
What are the principal impacts of the Trade Missions experience on student attitudes, traits and skills?

This exploratory study therefore focuses on the acquisition of soft skills and changes in attitudes by the students, rather than the acquisition of knowledge about international trade. Given that international trade knowledge acquisition goals are already measured using a broad range of graded activities, another pathway was prioritized, which appeared to us to be more promising. In other words, the focus is on outcomes leading to professional value rather than academic value, within the meaning assigned to these concepts by Kosnik et al. (2013).

\section{Sample and Context}

The cohort observed in this study was the group of 41 students who participated in the Trade Missions from fall 2015 to summer 2016. More than two thirds of the respondents were enrolled in a business program (17 BBA and 10 MBA students), where the remaining respondents were from international studies (8) or other programs (law, engineering, public affairs). The majority of the participants were undergraduate students $(67 \%)$, almost evenly distributed among gender.

Missions for 2015-2016 were held in the following countries: South Korea (12 mandates), India (14 mandates), and Mexico (17 mandates). The mandating businesses were for the most part small businesses: roughly half of them had sales of less than $\$ 10$ million and $60 \%$ had less than $\$ 25$ million. More than half of the businesses were located within a radius of 100 miles of the city of Québec, 24\% were in the Montréal area and the rest were distributed across the other regions of the Province of Québec.

\section{Data Collection Method}

Before developing a questionnaire, a qualitative analysis of the experience summaries submitted by the students from previous cohorts was conducted to identify the main impacts of the Trade Missions experience on the students. On the basis of this analysis, a questionnaire was subsequently developed. A first set of questions targeted changes observed in attitudes and personality traits, a second set targeted improved communications and sales skills and techniques, and the last set dealt with the acquisition of professional skills.

In order to identify the potential effect of the Trade Missions experience, an initial measure was taken in fall 2015, before the students began their training and just after being recruited. A second measure was taken upon their return from the Mission in summer 2016. A questionnaire was administered online to all Trade Missions 2015-2016 participants with a $90 \%$ response rate for the first survey $(n=37)$ and $83 \%$ for the second $(n=34)$. However, only 25 students responded to both questionnaires (61\% of participants).

During the initial measure, for each question, students were asked to indicate whether they had improved their attitudes, traits, competencies or skills throughout their university education. Possible answers ranged from (1) No, totally disagree to (5) Yes, totally agree. Upon their return from their Mission, they were asked the same questions, the only difference this time being that the questions referred specifically to the impact of their Trade Missions experience ("Throughout your experience with the Trade Missions, did you improve: ....").

\section{RESULTS}

Given that several students had only replied to one of the two questionnaires and that we did not want to lose the wealth of information collected from them, a repeated ANOVA analysis was conducted. This option was available to us as the missing data appeared to be randomly distributed.

The sections that follow provide the descriptive statistics (estimates of least squares means and standard error) of the various learning dimensions measured and the $\rho$ value of the F tests performed, along with relevant comments. As will be demonstrated, participating in a business consulting project such as the Trade Missions helps students improve a number of attitudes and competencies. The impact is greatest on communications and sales skills and techniques ( $\rho$ $<.0001)$ and professional skills $(\rho<.0001)$, followed by attitudes and traits $(\rho=.0001)$. 


\section{Communications and Sales Skills and Techniques}

It is in this area that the learning outcomes are most significant (see Table 2 next page). It should be mentioned that, in most case, these skills are not usually taught at the university (e.g. cold calling techniques) and were therefore underdeveloped among students at the beginning of the Trade Missions (pre-TM mean score of 3.09/5).

The most improved sales skills were knowing how to represent a business and, to a lesser degree, the ability to identify needs, to persuade and to sell a product. This can probably be explained by the fact that several students hold parttime jobs during their studies or summer jobs working in retail or food and beverage establishments. They have therefore already had a hand in selling products and services. On the other hand, knowing how to represent a client is a new skill and opportunities to practice it are rather scarce in a university environment.

The sales skill that improved the least (but still significant at $\rho$.0134) is the ability to promote one's competencies. This can be explained by the fact that, to convince recruiters to select them, students must already be good at promoting themselves. The pre-TM mean score for this skill was indeed high at 4.02/5.

As for sales techniques, the largest gains were in the areas of cold calling and appointment preparation and follow-up techniques $(\rho<.0001)$. The improvement in giving a sales pitch was also very significant but the gain was relatively smaller with a pre-TM mean score of 3.10/5. This can probably be explained by the fact that business students have many opportunities in their studies to practice these techniques, such as when they participate in interuniversity games or certain entrepreneurship or communications courses.

Table 2. Development of communications and sales skills and techniques

\begin{tabular}{|c|c|c|c|c|c|}
\hline Dimension Measured & $\begin{array}{l}\text { Pre-TM } \\
\text { Mean } \\
\mathbf{n}=\mathbf{3 7}\end{array}$ & $\begin{array}{l}\text { Pre-TM } \\
\text { Standard } \\
\text { error }\end{array}$ & $\begin{array}{l}\text { Post-TM } \\
\text { Mean } \\
\text { n = } 34\end{array}$ & $\begin{array}{l}\text { Post-TM } \\
\text { Standard } \\
\text { error }\end{array}$ & $\begin{array}{l}\text { F test } \\
\rho \text { value }\end{array}$ \\
\hline Persuading others & 3.70 & 0.17 & 4.47 & 0.13 & $0.0003^{* *}$ \\
\hline Promoting one's competencies & 4.02 & 0.13 & 4.47 & 0.11 & $0.0134^{*}$ \\
\hline Knowing how to sell a product & 3.32 & 0.22 & 4.64 & 0.12 & $<0.0001^{* * *}$ \\
\hline Knowing how to represent a business & 2.95 & 0.22 & 4.88 & 0.06 & $<0.0001^{* * *}$ \\
\hline Identifying the needs of others & 3.68 & 0.17 & 4.70 & 0.09 & $<0.0001^{* * *}$ \\
\hline Cold calling techniques & 2.18 & 0.25 & 4.74 & 0.09 & $<0.0001^{* * *}$ \\
\hline Sales pitch techniques & 3.10 & 0.27 & 4.56 & 0.12 & $<0.0001^{* * *}$ \\
\hline Appointment preparation techniques & 2.53 & 0.23 & 4.65 & 0.09 & $<0.0001^{* * *}$ \\
\hline Appointment follow-up techniques & 2.27 & 0.23 & 4.62 & 0.11 & $<0.0001^{* * *}$ \\
\hline Mean for all dimensions & 3.09 & 0.16 & 4.64 & 0.06 & $<0.0001^{* * *}$ \\
\hline
\end{tabular}

Missions level: Mean = estimate of least square means; * significant at $\rho \leq .10 ; * *$ significant at $\rho \leq .01 ; * * *$ significant at $\rho \leq .0001$ 


\section{Development of General Professional Skills}

One professional skill that improved considerably was fluency in a foreign language (see Table 3 next page). At first glance, this may seem surprising. The working language for the missions in India and South Korea was English and practically all of the students that were recruited for these Missions were already fluent in English. As for students who had chosen Mexico as their mission destination, they were required to have at least intermediate-level Spanish skills. However, it should be recalled that the question students were asked during the initial measure consisted of finding out whether they had improved their foreign language skills as part of their university education. Thus, the vast majority of students spoke English fluently even before enrolling at Université Laval, which resulted in rather low pre-TM mean score of 3.60/5. In addition, as part of the Trade Missions, the students were required to complete a 45-hour language course to acquire business vocabulary and prepare them to negotiate in English or Spanish, which explains the high post-TM mean score of 4.65/5).

It is interesting to note that the missions enabled the students to develop certain personality traits that are often associated with entrepreneurs, namely, the ability to identify business opportunities and the capacity to adapt quickly to unforeseen situations, both very significantly $(\rho<.0001)$. This is also true for self-confidence and taking initiative, as discussed in the following section. It should be noted that many former officers are now in business.

It bears repeating that the mandate-seeking exercise is a team effort, which one would assume would considerably improve the students' ability to work effectively as a team. However, this skill did not improve significantly. This can probably be explained by the fact that students learn to work as a team from the moment they begin their university studies, and it is therefore difficult to improve a skill that is already fairly well developed (pre TM mean score of 4.38/5). Similar results were obtained for managing one's stress: with a pre TM mean score of $4.12 / 5$, the recruited students already managed their stress effectively before joining the Trade Missions.

Table 3. Development of general professional skills

\begin{tabular}{l|c|c|c|c|c}
\hline \multicolumn{1}{|c}{ Dimension Measured } & $\begin{array}{c}\text { Pre-TM } \\
\text { Mean } \\
\mathbf{n = 3 7}\end{array}$ & $\begin{array}{c}\text { Pre-TM } \\
\text { Standard } \\
\text { error }\end{array}$ & $\begin{array}{c}\text { Post-TM } \\
\text { Mean } \\
\mathbf{n = 3 4}\end{array}$ & $\begin{array}{c}\text { Post-TM } \\
\text { Standard } \\
\text { error }\end{array}$ & $\begin{array}{c}\text { F test } \\
\boldsymbol{\rho} \text { value }\end{array}$ \\
\hline $\begin{array}{l}\text { Knowing how to conduct oneself in } \\
\text { meetings with business people }\end{array}$ & 3.71 & 0.19 & 4.50 & 0.13 & $0.001^{* *}$ \\
\hline Adapting quickly to unforeseen situations & 3.74 & 0.15 & 4.59 & 0.11 & $<0.0001^{* * *}$ \\
\hline Adapting to a foreign culture & 4.00 & 0.21 & 4.68 & 0.09 & $0.0048^{* *}$ \\
\hline Managing one's stress & 4.12 & 0.16 & 4.38 & 0.11 & 0.1365 \\
\hline Identifying business opportunities & 3.38 & 0.20 & 4.62 & 0.11 & $<0.0001^{* * *}$ \\
\hline Working efficiently as a team & 4.38 & 0.11 & 4.61 & 0.11 & 0.1817 \\
\hline Developing foreign language skills & 3.60 & 0.22 & 4.65 & 0.09 & $<0.0001^{* * *}$ \\
\hline Mean for all dimensions & 3.85 & 0.11 & 4.57 & 0.07 & $<0.0001^{* * *}$ \\
\hline
\end{tabular}

Note: Scale questions ranged from 1 "No, totally disagree" to 5 "Yes, totally agree"; Pre-TM = before Trade Missions level; Post-TM = after Trade Missions level: Mean $=$ estimate of least square means; * significant at $\rho \leq .10 ; * *$ significant at $\rho \leq .01 ; * * *$ significant at $\rho \leq$.

\section{Development of Attitudes and Personality Traits}

Among attitudes and traits, the dimensions for which the results are the most striking is self-confidence and initiative. It is true that to surmount the many challenges involved in preparing and carrying out a trade mission, students have to take initiative and the success they achieve can feed their ego. This appreciation for self-confidence is even more tangible in contacts with older and more experienced individuals $(\rho<.0001)$. First, students have to interact with business leaders and experienced managers as they seek mandates. Second, they must work in close collaboration with the members of the mandating business, not to mention the many contacts they have to establish abroad with potential suppliers, buyers or distributors. These are outstanding business networking opportunities that seldom if ever occur as part of a regular university curriculum.

We have noted, however, that participating in the Trade Missions did not significantly help students become more independent, open-minded or persevering. For one thing, most students who are interested in participating in the Trade 
Missions have extensive travel experience and already have an open mind even before starting their mission (pre-TM mean score of 4.39/5). As for perseverance (pre-TM mean score of 4.57/5) and independence (pre-TM mean score of 4.41/5), these are qualities Trade Missions recruiters look for in potential officers because they have proven to be essential to the Missions' success. With regard to perseverance, students are required to display this quality throughout the mandate-seeking period, as they had to place many cold calls before getting an appointment, and not all appointments result in a mandate.

Table 4. Development of attitudes and personality traits

\begin{tabular}{l|c|c|c|c|c}
\hline \multicolumn{1}{|c}{ Dimension Measured } & $\begin{array}{c}\text { Pre-TM } \\
\text { Mean } \\
\mathbf{n}=\mathbf{3 7}\end{array}$ & $\begin{array}{c}\text { Pre-TM } \\
\text { Standard } \\
\text { error }\end{array}$ & $\begin{array}{c}\text { Post-TM } \\
\text { Mean } \\
\mathbf{n = 3 4}\end{array}$ & $\begin{array}{c}\text { Post-TM } \\
\text { Standard } \\
\text { error }\end{array}$ & $\begin{array}{c}\text { F test } \\
\boldsymbol{\rho} \text { value }\end{array}$ \\
\hline Self-confidence & 4.26 & 0.13 & 4.66 & 0.53 & $0.0023^{* *}$ \\
\hline Self-knowledge & 4.22 & 0.10 & 4.53 & 0.10 & $0.0105^{*}$ \\
\hline Independence & 4.41 & 0.12 & 4.62 & 0.11 & 0.2110 \\
\hline Initiative & 4.23 & 0.12 & 4.79 & 0.07 & $0.0002^{* *}$ \\
\hline Open-mindedness & 4.39 & 0.11 & 4.35 & 0.14 & 0.7637 \\
\hline Perseverance & 4.57 & 0.10 & 4.76 & 0.07 & 0.1156 \\
\hline $\begin{array}{l}\text { Self-confidence in communications } \\
\text { with more experienced individuals }\end{array}$ & 3.86 & 0.17 & 4.93 & 0.04 & $<0.0001^{* * *}$ \\
\hline Mean of all dimensions & 4.28 & 0.08 & 4.66 & 0.06 & $0.0001^{* * *}$ \\
\hline
\end{tabular}

Note: Scale questions ranged from 1 "No, totally disagree" to 5 "Yes, totally agree"; Pre-TM = before Trade Missions level; Post-TM = after Trade Missions level: Mean = estimate of least square means; * significant at $\rho \leq .10 ; * *$ significant at $\rho \leq .01 ; * * *$ significant at $\rho \leq .0001$

\section{DISCUSSION}

As was explained in the preceding section, participating in the Trade Missions has an undeniable and considerable impact on the students by helping them acquire professional skills and competencies and develop traits and attitudes. These learning outcomes are of the same nature as those identified in the literature review as having professional value (Kosnik et al., 2013). To the extent that the Trade Missions are designed to maximize experiential learning among students, this is hardly surprising, given the numerous benefits that result from this type of pedagogy in the reviewed literature. The question arises, however, as to what Trade Missions particularities contribute more specifically to making them a successful experiential learning opportunity.

The literature reviewed makes reference to the multiplier effect of collective reflection when a student's experience is discussed within a group or team at the reflective observation stage (Knapp, 2010; Miller \& Maellaro, 2016; Ohlsson, 2013). This is in fact precisely what happens with the Trade Missions. Right from the mandate-seeking period, students get together in the office they are assigned and discuss their successes and challenges among themselves, thus providing mutual encouragement. As was mentioned above, the responsibility to find mandates is shared by all. Students can also count on the support of a coordinator who is available at all times to coach them, listen to them, advise them and share their tricks with them. During the appointments with businesses, the officers are always accompanied, which provides yet another opportunity for experience sharing. Lastly, during the mission, a debriefing session is held every evening in which the day's events are discussed as a group and potential solutions are put forward. The students therefore often find themselves in a context of collective rather than individual reflection as they reflect on and critically examine and evaluate their experiences.

Another factor that is likely to contribute to student learning outcomes is the fact that the project extends over a period of nearly 10 months. On one hand, the students have time to develop trust with their peers, which facilitates the sharing of experience. In all likelihood, this helps create a "safe space" in which they feel comfortable in opening up to others without the fear of being judged (Kisfalvi \& Oliver, 2015; Kolb et al., 2014). On the other hand, the program provides students with opportunities for many different but complementary challenging experiences, each with its own learning loop. Challenging experiences promote learning as they force individuals to acquire new skills and knowledge and apply them to situations (Matsuo, 2015). In fact, it appears that the learning outcomes are driven by both experiential learning depth (amount of time commitment) and breadth (number of different types of experience). Studies by Coker, Heiser, Taylor and Book (2017) indeed indicate that breadth may have an edge over depth in terms of relational gains 
but depth has more impact on cognitive gains and higher order thinking. The experiences the students lived as part of the Trade Missions were both varied and distributed over a long period of time. It is therefore not surprising that the learning outcomes be considerable.

Beyond skills acquisition, the Trade Missions also have an impact on student employability. As of May 2017, all of the students from the cohort who had completed their studies were employed. From the 41 students in the cohort, seven were still studying. From the 34 other participants, eight students were hired by the business that had mandated their trade mission and were still working on international market development. It is also interesting to note that half (17) of the students who are employed work in the field of international trade (including those who are working for the mandating business). These data show that the students quickly find employment in connection with the expertise they developed as a result of their participation in the Trade Missions program. Furthermore, the data also confirm that an increasing number of businesses are using consulting projects as an integral part of their hiring process.

That being said, we cannot jump to the conclusion that projects such as the Trade Missions program should be generalized to the entire student body. In our opinion, certain winning conditions should be met for such initiatives to lead to significant learning outcomes. First, it should be pointed out that the students are hand-picked; they do not necessarily constitute a representative sample of Université Laval's student population. From the start, these students were open to this type of experience, which is rather destabilizing and extremely demanding. They had both the time and the desire to launch themselves into such an adventure and the program fit in well with their curriculum. They were the ideal candidates to take full advantage of this experiential learning opportunity, given that students with high learning autonomy respond well to such initiatives (Canhoto \& Murphy, 2016). In addition, it goes without saying that this type of academic project cannot be imposed on students; this can only remain an option for them. From a more practical standpoint, our experience in recent years suggests that no more than around 40 students should be selected for the project as a whole to be manageable and for that many mandates to be found.

Implementing academic projects of this type is no easy task. Expectations toward professors have greatly evolved in the last 20 years, as a result of which many professors focus primarily on their research activities rather than developing innovative teaching formulas, which can unfortunately be very time-consuming. In order for initiatives such as the Trade Missions to see the light of day, their value must be recognized by university authorities and those who champion these projects and shoulder their weight must be supported and rewarded.

\section{LIMITATIONS OF THE STUDY AND AVENUES FOR FUTURE RESEARCH}

The main limitations of this study are of a methodological nature. From the start, we should point to the small sample size, which involved a single cohort of only 41 students. It is therefore difficult to generalize the results in this context. In addition, the learning outcome measures were of a perceptual nature, as they were based on student impressions. These limitations also constitute avenues for future research: more objective learning outcome measurement tools could be developed or proven psychometric tests could be used with successive cohorts of Trade Missions participants.

In terms of avenues for future research, it would be interesting to identify the roles of experiential educators (Kolb et al., 2014) fulfilled by all of the individuals who intervene with the students throughout the Trade Missions. The most significant are undoubtedly the coordinators, who act as facilitators, evaluators and coaches, but the academic director and the executive director are also very involved in the students' learning, as they accompany them during their mission abroad. Not to mention the professional educators who lead workshops throughout the year on various international trade-related subjects, thereby fulfilling a role as a "subject expert". Having the opportunity to benefit from such a team of experiential educators with varied profiles could partly explain the success of the Trade Missions teaching formula.

On another note, it would be interesting to take a look at the spinoffs the Trade Missions generate for the businesses that mandate the students. For some, this is their first experience with international trade. It would be interesting to investigate the degree to which this first experience encourages them to develop international markets over the longer term. Given that a certain number of businesses hire the students that represented them as an officer, does this have a training effect on their international activities? It would also be relevant to investigate whether the effects vary according to the country in which the missions are held. Interestingly, almost every year, at least one of the three 
targeted markets is in a country with which Canada still has very little trade, which makes them more difficult to penetrate (e.g. Indonesia and Turkey). Does a successful mission in an unknown country with significant cultural differences help build confidence among businesses and encourage them to seek out more international opportunities or, on the contrary, are they discouraged by the difficulties they encounter? In short, there are boundless avenues for future research.

\section{CONCLUSION}

In response to the criticisms addressed to business schools, teaching formulas that foster experiential learning are increasingly being put forward. It so happens that the Trade Missions formula corresponds precisely to this type of teaching style. Our results show that student participation in an international trade mission has a considerable impact on the acquisition of professional skills and competencies, as well as the development of personality traits and attitudes. Through this experience, students build confidence, develop a sense of initiative and learn to identify business opportunities and adapt quickly. It allows them to sharpen their sales skills and techniques while learning to represent a business. Having completed a trade mission also appears to improve student employability, as a significant number of alumni have managed to find employment in the field of international trade. It would certainly be desirable for such learning opportunities to be made available to a greater number of students, but the considerable effort required to implement innovative projects that foster experiential learning cannot be underestimated.

\section{AUTHOR BIOGRAPHIES}

Josée Audet is a professor of Entrepreneurship at the Faculté des Sciences de l'Administration of Université Laval in Québec City, Canada. She received her MBA from McGill University and her Ph.D. from Université Laval. Her research interests include pedagogy, entrepreneurship and regional development.

Geneviève Marcotte is a DBA student at l'Université du Québec à Trois-Rivières. She received an MA in International Relations from Université Laval in 2012. She has been involved with the Université Laval Trade Missions since 2010, initially as a participant, and as executive director since 2013.

\section{REFERENCES}

Austin, M. J., \& Rust, D. Z. (2015). Developing an experiential learning program: Milestones and challenges. International Journal of Teaching \& Learning In Higher Education, 27(1), 143-153.

Bach, D. (2012). We need to rethink ... everything. BizEd (September/October), 18-24.

Bell, R., \& Bell, H. (2016). An enterprise opportunity for entrepreneurial students. Education \& Training, 58(7), $751-765$.

Brown, K. G., Ben Arbaugh, J., Hrivnak, G., \& Kenworthy, A. (2013). Overlooked and unappreciated: What research tells us about how teaching must change. In Graduate Management Admission Council (Ed.), Disrupt or be disrupted A blueprint for change in management education (pp. 219-259). San Fransisco, CA: Jossey-Bass.

Canhoto, A. I., \& Murphy, J. (2016). Learning from simulation design to better experiential learning initiatives: An integrative approach. Journal of Marketing Education, 38(2), 98-106.

Chmielewski-Raimondo, D., McKeown, W., \& Brooks, A. (2016). The field as our classroom: Applications in a businessrelated setting. Journal of Accounting Education, 34, 41.

Coker, J. J., Heiser, E., Taylor, L., \& Book, C. (2017). Impacts of Experiential Learning Depth and Breadth on Student Outcomes. Journal of Experiential Education, 40(1), 5-23.

Datar, S., Garvin, D., \& Cullen, P. (2010). Rethinking the MBA: Business education at a crossroads. Boston, MA: Harvard Business Press.

Deeter-Schmelz, D. (2015). Corporate-academic partnerships: Creating a win-win in the classroom. Journal of Education for Business, 90(4), 192.

Desjarlais, M., \& Smith, P. (2011). A comparative analysis of reflection and self-assessment. International Journal of Process Education, 3(1), 3-18.

George, M. P. (2015). Experiential learning to enhance work skills, empathy and entrepreneurship in business schools. Journal of Contemporary Research in Management, 10(3), 1-15.

Holtom, B. C. \& Porter, L. W. (2013). The change imperative. In Graduate Management Admission Council (Ed.), Disrupt or be disrupted A blueprint for change in management education (pp. 1-21). San Fransisco, CA: Jossey-Bass.

Hughes, S. \& Scholtz, F. (2015). Increasing the impact of a business simulation: The role of reflection. The International Journal of Management Education, 3, 350-361. 
Kisfalvi, V., \& Oliver, D. (2015). Creating and maintaining a safe space in experiential learning. Journal of Management Education, 39(6), 713.

Knapp, R. (2010). Collective (team) learning process models: A conceptual review. Human Resource Development Review, 9 , 285-299.

Kolb, A. \& Kolb, D. (2009). Experiential learning theory: a dynamic, holistic approach to management learning, education and development. In S. J. Armstrong \& C. V. Fukami The SAGE handbook of management learning, education and development (pp. 42-68). London: SAGE Publications Ltd. doi: 10.4135/9780857021038.n3

Kolb, D. A. (1984). Experiential learning. Englewood Cliffs, N.J.: Prentice Hall.

Kolb, A. Y., Kolb, D. A., Passarelli, A., \& Sharma, G. (2014). On becoming an experiential educator: The educator role profile. Simulation \& Gaming, 45(2), 204.

Kosnik, R. D., Tingle, J. K., \& Blanton III, E. L. (2013). Transformational learning in business education: The pivotal role of experiential learning projects. American Journal of Business Education (Online), 6(6), 613.

Le, Q. V., \& Raven, P. V. (2015). An assessment of experiential learning of global poverty issues through international service projects. Journal of Teaching in International Business, 26(2), 136.

Matsuo, M. (2015). A framework for facilitating experiential learning. Human Resource Development Review, $14(4), 442$.

Miller, R. J., \& Maellaro, R. (2016). Getting to the root of the problem in experiential learning: Using problem solving and collective reflection to improve learning outcomes. Journal of Management Education, 40(2), 170-193.

Ohlsson, J. (2013). Team learning: Collective reflection processes in teacher teams. Journal of Workplace Learning, 25, $296-309$.

Pfeffer, J., \& Fong, C. T. (2002). The end of business schools? Less success than meets the eye. Academy of Management Learning \& Education, 1, 78-95.

Ramburuth, P., \& Daniel S. (2011) Integrating experiential learning and cases in International Business. Journal of Teaching in International Business, 22(1), 38-50, doi: 10.1080/08975930.2011.585917.

Rubin, R. S., \& Dierdorff, E. C. (2011). On the road to Abilene: Time to manage agreement about MBA curricular relevance. Academy of Management Learning \& Education, 10, 148-161.

Rubin, R. S., \& Dierdorff, E. C. (2009). How relevant is the MBA? Assessing the alignment of required curricula and required managerial competencies. Academy of Management Learning \& Education, 8, 204-228.

Splan, R. K., Brooks, R. M., \& Porr, C. S. (2016). Student reflections on personal and professional growth after a 16-week immersive, experiential learning program in Equine Science. NACTA Journal, 60(1), 60-64. 